\title{
坂口可奈 著
}

\section{『シンガポールの奇跡 発展の秘訣と新たな課題』}

早稲田大学エウプラクシス叢書 2017年 iv +256頁

\section{神谷 茂子}

シンガポールは2015年に建国50周年を迎えた。1965年 8 月 9 日にマレーシア連邦 から突然分離独立することになったこの小さな都市国家は，いまや世界の注目を集め る経済大国へと成長した。建国50周年の盛大なパレードはまだ記憶に新しい。同じ年 に建国の父であるリー・クアンユがこの世を去ったこともまた，シンガポールの新た な節目を感じさせる出来事であった。本書は，都市国家シンガポールをとりあげ，こ の国がなぜここまで発展することができたのか，その成功の仕組みを解き明かすこと を目的に書かれたものであり, 著者が2014年に早稲田大学大学院政治学研究科に提 出した博士論文を加筆修正したものである。章構成は以下の通りである。

序章 なぜ今, シンガポールなのか

第 1 章 シンガポールという国

第 2 章 多民族国家

第 3 章 能力主義国家シンガポール

第 4 章 シンガポールの社会保障

第 5 章 移民とシンガポール

第 6 章 これからのシンガポール

おわりに

序章で，本書の目的はシンガポールの成功の仕組みを全体的に解明することとして いる。従来のシンガポール研究について, その意義を評価しつつも, それぞれの研究 が特定の分野に特化していること，マジョリティ，エリートなどの「強者」に焦点を 置いてきたものであることを指摘し, 本書ではシンガポールの「弱者」にも視野を広 げてその国家建設を「より包括的に分析する」と述べている。そのためには，「多民 
族国家」「能力主義国家」「移民国家」という「シンガポールの特徵」と，「それを 生み出してきた主体」である人民行動党を視野に入れる必要があるという。ただし， 分析対象は彼らの政策自体だけでなく，「国家神話」，つまり「政策の背景にある国家 建設の軸となる考え方」を含む。シンガポールの「国家神話」とは，「多人種主義」 と能力主義をさし，この 2 つがシンガポールの発展をどう支えてきたかを「シンガポ ールの文脈」を重視して分析したいとしている。

第 1 章では，複数のエスニシティに焦点を当てながら，テマセック時代から1965年 の分離独立までのシンガポールの歴史を概説し，「多人種主義」と能力主義を採用し た背景を説明している。つづけて，独立後の「国家としての生き残り」を第一優先に 国家建設を進めていくシンガポールの経済発展の背景を概説し，シンガポールのプラ グマティズムがシンガポール経済を支えたのと同時に生み出した社会の脆弱性につい て指摘している。

第 2 章では「多人種主義」という概念の定義と，そのメカニズムの分析，さいごに その功罪についてのまとめをしている。本書ではシンガポールのエスニシティやエス ニック・グループを「人種」のサブカテゴリーとして扱い，「人種」のさらに高度な 概念として「シンガポール」が存在する三層の構造で示している。また，シンガポー ルで巧妙に作られた華人，マレー人，インド人，その他という4「人種」分類は，実 は真のエスニシティを見えづらくし，どの分類にも包摂されない，「マイノリティの中 のマイノリテイ」を生み出しているという。「多人種主義」については，リベラル文 化主義とコーポレイト多文化主義とを比較し，アイデンティティを生み出す空間とし て，外国（人）に対してふるまう「高位の公的空間」，他「人種」に対してふるまう 「低位の公的空間」，政治的な力が及ばない，真のエスニシティを発揮できる「私的空 間」に分け，このような空間の関係性において，シンガポールの「多人種主義」はリ ベラル文化主義とコーポレイト多文化主義が併存する複雑な様相を呈しながらエスニ シティを私的空間に追いやってきたと指摘している。また，現在の「多人種主義」は 移民によるエスニシティ増加に対応できていないため，おさまりきらないエスニシテ イが国内安定を脅かしつつあるとも論じている。

第 3 章では, シンガポールの能力主義について, 教育システムに焦点を当てて分析 している。人的資源しか頼るものがなかったシンガポールは徹底した能力主義を採用 し，その中でも有能な人材の発掘・育成を効率的に行うために教育を重要視してきた。 本章ではシンガポールの教育システムを，「生き残り志向教育」(1965年〜1978年), 「効率志向教育」（1979年～1996年），能力志向教育（1997年～2011年），価値志向教 育（2012年以降）の 4 つに分け，教育システムと経済構造変化の時期区分の連関性 を指摘している。つぎに，能力志向教育期（1997年～2011年）における試験での選抜 
という特徴を論じている。奨学金を受けるような「最上級エリート」になれるかは実 質高校入学の段階で決まるため，実態として家庭内の環境の違いが影響し，格差が 再生産され，社会階層が固定化するリスクをはらむ。そして，能力主義によって「失 敗」した人々が社会の主流から排除されていく状況は, 成功=経済的成功, 経済成 功のためには学歴が必要であるという一元的価值観を社会に植え付け, 経済発展後 のシンガポールでは成熟した国家への成長を阻害していると述べている。

第 4 章では，引き続き能力主義を，主に社会主義制度に焦点を当てて論じている。 シンガポールの社会保障体制は，「儒教型社会保障体制」と呼ばれ，政府による直接 的な現金支給ではない。社会保障制度の中心をなす中央積立基金は強制積立貯金の 性格を持つが，低所得者にとつて非常に厳しく，その援助体制についても，「自立」 と自助努力を前提とした勤労福祉（ワークフェア）のかたちをとっている。2005年に より包括的な援助であるコムケアが設立したが，資格条件が㛜しく，低所得者全体を カバーできていない。一方，シンガポールには民間援助である「人種」別自助組織も 存在するが，「人種」意識を促進させ，「多人種国家」シンガポールの国家神話を支 えてきた。ゴー・チョクトン時代になると，政府の社会保障に対する意識が変わり， 「多種多様な支援アプローチ」について政府は自らを援助の担い手の「一部」として 認めるとともに, 人々にも責任を分担するシステムとなり, 前述のコムケアなどが生 まれた。ただし，結局シンガポールの社会保障制度は，受給者が㗢けること，努力す ること（しかも努力が報われること），シンガポールが経済成長を持続することを前 提としており, 制度から疎外される人々を生み出しているとともに, 将来的なシンガ ポールの経済の停滞に対応できない可能性があり, 改善すべきであると著者は説いて いる。

第 5 章ではシンガポールの移民が国家建設に与える影響を分析している。まず移 民を専門性の高い高度人材と外国人労働者，そしてシンガポール国籍をとつた新国民 に分類している。高度人材は経済発展を最大化させる戦略として優遇されるのに対し， 外国人労働者は「使い捨て」ベースで扱われる。前者は国内の競争の激化に対する 国民の不安を招き，政府を悩ませてもいる。国内からの頭脳流出の問題もあり，政治 的にはその穴は外国人では埋められないため，深刻な問題である。一方，新国民は， その必要性を理解されつつも, シンガポール人との間に緊張感を生み出してきたため, 政府も腐心して新国民統合に取り組んでいる。急速な経済発展に伴う人手不足は家 庭内労働を担うメイドという新たな外国人労㗢者も生み出した。例えばフィリピン人 メイドはコミュニティを形成しているが，政府の規定する「多人種主義」の範疇から は外にいる存在である。範疇外の存在の増加は, 従来の「多人種主義」の維持を難 しくしている。このように移民は，シンガポールの経済発展を支えてきたと同時に， 
経済のみならず国民の日常生活を外国人に依存する構造を生み出し，「多人種主義」 や能力主義といった「国家神話」の脆弱性を顕在化させる存在でもあったと論じてい る。

第 6 章は「安定」と「推進」の力をキーワードとして本文のまとめをしている。ま ず，シンガポールは社会秩序の維持と民族間対立の防止によって「安定」の力を持て た。また，「4 つの民族性，1つの成功」という一元的価値観の下で大衆とエリート の間で成功＝経済的成功という価値観を共有できたことで，「推進」の力を発揮でき た。しかし生き残りのために進められた一元的な価值観による支配は，経済発展の恩 恵を昔ほど実感できなくなった現在においては，むしろ弊害をもたらしている。こう した弊害に対し著者は「4つの多様性，経済的成功のための能力」から「多様な工 スニシティ，多様な成功」へ転換することを提案し，締めくくっている。

まず，通読して印象に残ったのは，「多人種主義」という用語である。「人種」とい う用語に初見では違和感を覚えたが，本書のシンガポールの文脈で使用される「人 種（race）」はイギリス植民地統治下に起源をもつ用語であり，アメリカの人種差別 的な文脈を含むものではないことを強調し，シンガポールの「人種」概念をあらわす 用語として選択したことが本文で述べられている(52頁)。

次に本書の意義について考えたい。従来，国家としてのシンガポールの発展を政治 学的に分析した主要な研究としては，華人と国家に焦点を当てた田中 [1984; 2002], 国家もアクターのひとつという視点で国家としての機能や制度といった支配する側の メカニズムを分析した岩崎 [2005]，ナショナリズム，エスニシティ，ジェンダーの 視点から国家の「生き残りのイデオロギー」を分析した田村 [2000; 2013］の研究な どが挙げられるだろう。田中［1984］と本書は「シンガポールの奇跡」という夕イト ルキーワードが重なっているが，本書では国家としてさらに年数を経て，ますます発 展していく陰で様々な課題も表出してきたシンガポールについて，教育制度や社会保 障制度，移民問題に目配りしながら，特に華人以外の移民に関して従来と比べて大き く焦点を当てた分析を試みている。これは，あえて特定の対象に絞らず，幅広くシン ガポールを考察したいという著者の意図を反映したものだうう。シンガポールという 国家の，多民族国家 (「多人種主義」），能力主義国家（教育制度，社会保障制度）, 移民国家（外国人労㗢者・外国人人材）という特徵と，それを生み出した主体（人民 行動党）という構図を揭げ，それについて特定のエスニシティに絞り込まず，複数の エスニシティに目配せしながら整理分析しょうという本書の姿勢は，多様なエスニシ ティを抱えるシンガポールという問題を再認識させてくれる。シンガポール研究が, エリート側の「強者」を中心に分析されてきたという著者の指摘に関しては，近年， 「弱者」の側にも焦点を当てた議論も徐々に増えてきたことを補足したい。1950年代 
に設立され，「権力に祝福されない」大学として1980年代に「消滅」した南洋大学に ついて扱った田村［2013］や，シンガポールにおける華人の移民先への帰属過程に ついて扱った篠崎［2004］などが例として挙げられる。本書は，シンガポールは発展 と生き残りのために「多人種主義」と「能力主義」に邁進し，その過程で社会の周辺 に追いやられた「弱者」を生み出してきたとし，そのことがまさに，現在のシンガポ 一ルが国家として生き残り続けることを危険にさらしていると指摘しており，上述し たような「弱者」にも目配せした新しい潮流を担っていく視座を持った研究であると 言えるだろう。さいごに，本書はシンガポールの政策や制度を分析し，そこから置い て行かれた人々を浮かび上がらせ，彼らがシンガポールの政治において今後不安定 要素になりうることを指摘しているが，本書を読んだことをきっかけに，本書でとり あげられている施策や対応に国民の側は実際どのような不安や不満を抱えているのか 興味を持った。「シンガポールに住む人の立場によりそって「内在的理解」をしなが ら論じていきたい」とする，著者の今後の研究のますますの発展を期待したい。

\section{参考文献}

岩崎育夫. 2005.『シンガポール国家の研究:「秩序と成長」の制度化・機能・アクター』風 響社.

篠崎香織. 2004、「シンガポール華人商業会議所の設立 (1906年) とその背景 : 移民による出 身国での安全確保と出身国との関係強化」『アジア研究』50 (4): 1-14.

田村慶子.2000、『シンガポールの国家建設：ナショナリズム，エスニシティ，ジェンダー』 明石書店。

—. 2013.『多民族国家シンガポールの政治と言語：消滅した南洋大学の25年』明石書店． 田中恭子.1984.『シンガポールの奇跡：お雇い教師の見た国づくり』中公新書． 一一. 2002. 『国家と移民』名古屋大学出版会.

（連絡先：shigekmy@gmail.com） 